\title{
Cloning, expression and characterization of three types of $17 \beta$-hydroxysteroid dehydrogenases from the Nile tilapia, Oreochromis niloticus
}

\author{
L Y Zhou 1,3,4, D S Wang ${ }^{1,2,4}$, B Senthilkumaran 1,2,5, M Yoshikuni ${ }^{1,2}$, Y Shibata ${ }^{1,2}$, \\ T Kobayashi ${ }^{1,2,6}$, C C Sudhakumari ${ }^{1,2}$ and $Y$ Nagahama $^{1,2,3}$ \\ ${ }^{1}$ Laboratory of Reproductive Biology, Department of Developmental Biology, National Institute for Basic Biology, Okazaki 444-8585, Japan \\ ${ }^{2}$ Core Research for Evolutional Science and Technology (CREST), Kawaguchi, Saitama 332-0012, Japan \\ ${ }^{3}$ Department of Molecular Biomechanics, Graduate University for Advanced Studies, Okazaki 444-8585, Japan \\ ${ }^{4}$ Faculty of Life Sciences, Southwest China Normal University, 400715, Chongqing, P.R. China \\ ${ }^{5}$ Department of Animal Sciences, School of Life Sciences, University of Hyderabad, P.O. Central University, Gachibowli, Hyderbad 500 046, Andhra Pradesh State, India \\ ${ }^{6}$ National Research Institute of Aquaculture, Tamaki, Mie 516-0423, Japan
}

(Requests for offprints should be addressed to Y Nagahama; Email: nagahama@ nibb.ac.jp)

\begin{abstract}
In order to elucidate the roles of $17 \beta$-HSDs in fish gonadal steroidogenesis, three types of $17 \beta$-HSDs (17 $\beta$-HSD1, $17 \beta$-HSD8 and putative 17 $\beta$-HSD12) were cloned and characterized from the Nile tilapia, Oreochromis niloticus. The cloned cDNAs of 17 $\beta$-HSD type 1, 8 and 12 were 1504, 1006 and $1930 \mathrm{bp}$ long, with open reading frames encoding proteins of 289, 256 and 314 aminoacids, respectively. Tissue distribution pattern analyzed by RT-PCR and Northern blot showed that $17 \beta-\mathrm{HSD} 1$ was dominantly expressed in the ovary, while the putative $17 \beta-\mathrm{HSD} 12$, one of the two duplicates found in fish, is a male specific enzyme and expressed exclusively in testis (detected by RT-PCR only). On the other hand, 17 $\beta$-HSD8 was expressed in the brain, gill, heart, liver, intestine, gonad, kidney and muscle of both male and female. Enzymatic assays of the three types of $17 \beta$-HSDs were performed using recombinant proteins expressed in E. coli or HEK 293 cells. Tilapia 17 $\beta$-HSD1 expressed in E. coli had the preference for NADP(H) as cofactor and could catalyze the inter-conversion between estrone and estradiol efficiently as well as the inter-conversion between androstenedione and testosterone, but less efficiently. Tilapia 17 $\beta$-HSD8 recombinant protein expressed in HEK 293 cells could catalyze the conversion of testosterone to androstenedione, as well as the inter-conversion between estrone and estradiol. However, the putative 17 $\beta$-HSD12 expressed in E. coli or in HEK 293 cells showed no conversion to any of the four substrates tested in this study. Based on enzyme characterization and tissue distribution, it is plausible to attribute crucial roles to $17 \beta-\mathrm{HSD}$ in the gonadal steroidogenesis of teleosts.
\end{abstract}

Journal of Molecular Endocrinology (2005) 35, 103-116

\section{Introduction}

17 $\beta$-hydroxysteroid dehydrogenases (17 $\beta$-HSDs) are remarkably multifunctional enzymes that modulate the synthesis and metabolism of sex steroids in gonadal tissues by catalyzing the conversion of 17 -ketosteroids (dehydroepiandrosterone, androstenedione (A), and estrone $\left(\mathrm{E}_{1}\right)$ ) into $17 \beta$-hydroxysteroids (androstenediol, testosterone $(\mathrm{T})$, and estradiol-17 $\left.\beta\left(\mathrm{E}_{2}\right)\right)$, and vice versa. To date, multiple types of $17 \beta$-HSDs, which belong to two protein superfamilies: short chain dehydrogenase/ reductase (SDR) and aldo-ketoreductase (AKR), have been isolated and characterized in mammals (Puranen et al. 1997, Oppermann et al. 1999, Penning et al. 2003, Mindnich et al. 2004b). More importantly, each type of $17 \beta$-HSDs differs from each other in substrate specificities, catalytic coenzyme preference, biochemical properties and in particular, tissue distribution (Poirier 2003). Therefore, different isozymes might possess different physiological function in the steroidogenic pathway.

$17 \beta$-HSD1, which had been characterized in mouse, human, rat, chicken, Japanese eel and zebrafish (Poutanen et al. 1993, Akinola et al. 1996, 1998, Nokelainen et al. 1996, Wajima et al. 1999, Kazeto et al. 2000, Mindnich et al. 2004a), is a key enzyme dominantly catalyzing the final step of the synthesis of $\mathrm{E}_{2}$. The enzymatic activity to convert $\mathrm{A}$ to $\mathrm{T}$ by $17 \beta$-HSD 1 was found only in mice and rats (Nokelainen et al. 1996, Akinola et al. 1996). In accordance to these, $17 \beta$-HSD 1 is abundantly expressed in the ovary of those species, as well as in the adrenal and mammary glands, uterus, placenta, and endometrium of mice (Poutanen et al. 1995). 
The functional protein encoded by the Ke 6 gene has been determined to be $17 \beta$-HSD8. Previously, the abnormal expression of $\mathrm{Ke} 6$ gene has been closely associated with development of recessive polycystic kidney disease (Fomitcheva et al.1998, Ramirez et al. 1998). In humans and mice, Ke 6 is linked to the major histocompatibility complex (MHC) class II region, whereas in zebrafish and medake it is linked to MHC class I region (Sultmann et al. 2000, Matsuo et al. 2002). Mouse 17 $\beta$-HSD8 efficiently catalyzes the oxidation of $\mathrm{E}_{2}, \mathrm{~T}$, and dihydrotestosterone and the reduction of $\mathrm{E}_{1}$ to $\mathrm{E}_{2}$. Therefore, $17 \beta$-HSD8 could be essential for the development of both kidney and gonad by regulating the reduction or oxidation of $\mathrm{E}_{2}, \mathrm{~T}$, and dihydrotestosterone, and vice versa maintaining the optimal levels of sex steroids within these organs (Fomitcheva et al. 1998).

$17 \beta$-HSD12 is the most recent addition to this enzyme family and subsequent phylogenetic analysis revealed its close relationship to $17 \beta-\mathrm{HSD} 3$ (Mindnich et al. 2004a). Interestingly, 17 $\beta$-HSD3, which is predominantly expressed in testis, is responsible for the conversion of A to T. Therefore, it is one of the crucial steroidogenic enzymes required for normal male sexual development (Baker et al. 1997, Bilbao et al. 1998, Moghrabi et al. 1998). Moreover, the orthologs of $17 \beta$-HSD12 have been characterized in humans (AAP36605), mice (NP_062631), rats (NP_114455), Xenopus (BC041194) and zebrafish (A (AAH63943) and B (NP_955907)). It is ubiquitously expressed with highest levels in liver, muscle and kidney, both in humans and mice. Human and mice $17 \beta-H S D 12$ s were demonstrated to have substrate specificity and function in fatty acid elongation (reduction of 3-ketostearoyl-CoA to 3-hydroxystearoyl-CoA). Putative homologs of 17及HSD 12 have also been reported in yeast (YBR159w) and Caenorhabditis elegans (LET-767) (Beaudoin et al. 2002, Kuervers et al. 2003). Interestingly in the C. elegans, $17 \beta$-HSD 12 seems to be involved in the modification of sterol derivatives and its deletion affects embryogenesis, molting and female reproduction. However, in vertebrates, presence of catalytic activity towards steroids by $17 \beta$-HSD 12 has not been demonstrated so far.

$17 \beta$-HSDs are required for the production of $\mathrm{E}_{2}$ and 11-Ketotestosterone with seemingly important roles in the process of sex differentiation and gametogenesis in fish (Guiguen 2000, Mindnich et al. 2004a). However, most of the data on $17 \beta-H S D$ s are from mammals, except for $17 \beta$-HSD1 cloned and characterized from chickens, zebrafish and the Japanese eel. It is well known that sex steroids play important roles in the process of sex differentiation and gametogenesis of non-mammalian vertebrates (Nagahama 2000). In order to elucidate the roles of $17 \beta$-HSDs and get more insights into the steroidogenic pathway in fish, we undertook the cloning and characterization of the three types of $17 \beta$-HSDs in the Nile tilapia, Oreochromis niloticus. To our knowledge, cDNA cloning and enzymatic characterization of $17 \beta$-HSD type 8 has not been reported in any non-mammalian vertebrate.

\section{Materials and methods}

\section{Animals}

Tilapia was reared in 1 ton tanks with re-circulating aerated fresh water systems. Fish were maintained at ambient temperature $\left(24 \pm 1{ }^{\circ} \mathrm{C}\right)$ under natural light conditions. Mature tilapia (XX) that spawn once in every 2 weeks, at an average of 14-18 days, were used in the present study.

\section{cDNA cloning of three types of tilapia $17 \beta-H S D s$}

\section{Cloning of full length $c D N A$ of $17 \beta-H S D 1$}

A 548 bp cDNA fragment of $17 \beta-H S D 1$ was amplified from the ovary by RT-PCR with degenerate primers $\left(1-1 F_{W}, 1-1 R_{v}\right)$ designed from the conserved region of human, mouse, chicken and Japanese eel 17 $\beta$-HSD 1 s. Tilapia ovarian follicular cDNA UNI-ZAP XR library was constructed according to the manufacturer's instruction (Stratagene, La Jolla, CA, USA). By using the ${ }^{32}$ P-labeled cDNA fragment of 17 $\beta$-HSDl obtained from RT-PCR as a probe, about $10^{6}$ independent plaques of tilapia ovary cDNA library were screened under high-stringency hybridization conditions and the positive clones were obtained after three rounds of screening. In vitro excision and rescue of pBluescript phagemids were performed according to the manufacturer's protocol to obtain the full-length $\mathrm{cDNA}$ sequence of $17 \beta$-HSD1.

\section{Cloning of $17 \beta-H S D 8$ and $17 \beta-H S D 12$ cDNAs}

A $260 \mathrm{bp}$ cDNA fragment of tilapia 17 $\beta$-HSD8, including 3 '-untranslated region (UTR) and partial open reading frame $(\mathrm{ORF})$, was obtained from tilapia EST (Expression Sequence Tag) clones. Subsequently, 5'rapid amplification of CDNA end (RACE) was performed according to the manufacturer's instructions (SMART RACE cDNA Amplification Kit, Clontech, CA, USA) with gene specific primers $(8-1 \mathrm{Rv}, 8-2 \mathrm{Rv})$. Gene specific primers $\left(8-3 \mathrm{Fw}_{\mathrm{w}}, 8-4 \mathrm{Rv}\right)$ were designed basing on the $3^{\prime}$ - and $5^{\prime}$-UTRs sequence to amplify the full length cDNA of $17 \beta$-HSD8.

In order to obtain a fragment of $17 \beta-\mathrm{HSD} 12 \mathrm{cDNA}$, a blast search of fugu (Fugu rubripes) genome (http:// www.ncbi.nlm.nih.gov/BLAST/Genome/fugu.html) was performed with human 17 $\beta$-HSD12 cDNA sequences. Through blast search we identified two $17 \beta$-HSD 12-like genes in fugu. We obtained their 
Table 1 Sequence of primers used for PCR and RACE

Primer sequences

\begin{tabular}{|c|}
\hline $\begin{array}{l}\text { Name } \\
(1-1 F w) \\
(1-2 R v) \\
(1-3 F w) \\
(1-4 R v) \\
(1-5 F w) \\
(1-6 R v) \\
(8-1 R v) \\
(8-2 R v) \\
(8-3 F w) \\
(8-4 R v) \\
(8-5 F w) \\
(8-6 R v) \\
(12-1 F w) \\
(12-2 R v) \\
(12-3 F w) \\
(12-4 F w) \\
(12-5 R v) \\
(12-6 R v) \\
(12-7 F w) \\
(12-8 R v) \\
(12-9 F w) \\
(12-10 R v) \\
\beta-a c t i n(F w \\
\beta-a c i n(R v)\end{array}$ \\
\hline
\end{tabular}

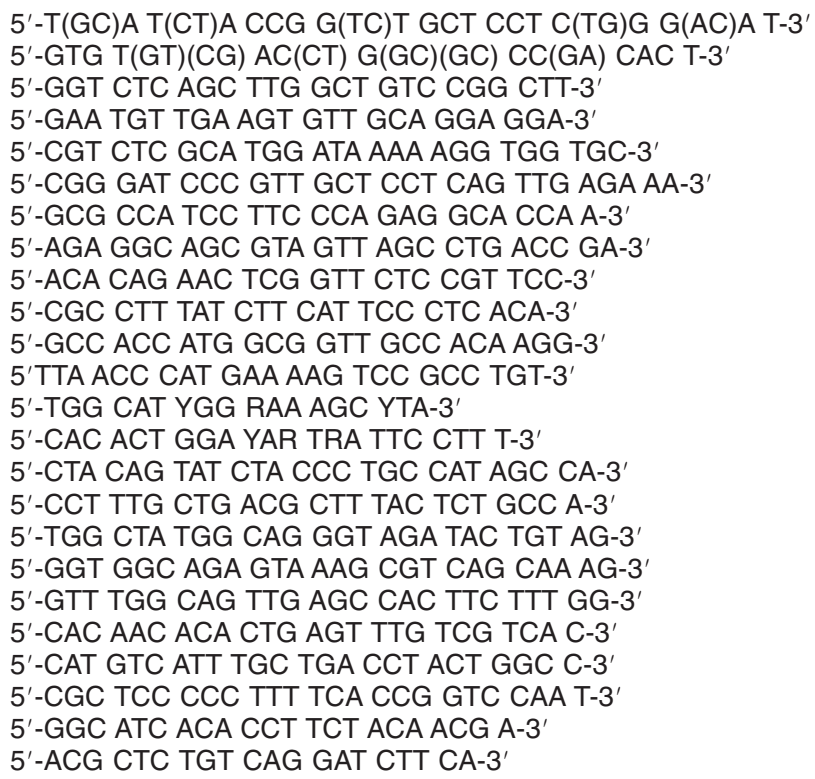

cDNA and amino acid sequences by carefully locating their intron and exon boundaries. Then, a pair of degenerate primers $(12-1 \mathrm{Fw}, 12-2 \mathrm{Rv})$ were designed in the conserved region of the nucleotide sequences of human, mouse, rat $17 \beta-\mathrm{HSD} 12$ and putative fugu $17 \beta$-HSD12s. A $516 \mathrm{bp}$ fragment of putative $17 \beta-$ HSD 12 was amplified from the testis of tilapia by RT-PCR with the degenerate primers. Subsequently, $5^{\prime}$ and $3^{\prime}$-RACE were performed by using four gene specific primers $(12-3 \mathrm{Fw}, 12-4 \mathrm{Fw}, 12-5 \mathrm{Rv}, 12-6 \mathrm{Rv})$. Finally, the full length putative $17 \beta$-HSD 12 cDNA was obtained from the testis of tilapia by using gene specific primers $(12-7 \mathrm{Fw}, 12-8 \mathrm{Rv})$ designed according to the sequence of $5^{\prime}$ - and 3 '-UTRs.

All the cDNA fragments obtained by PCR were purified by agarose gel electrophoresis, followed by subcloning into pGEM-T Easy Vector (Promega, Madison, WI, USA) for nucleotide sequencing. All clones were sequenced bidirectionally using vector-based and/or gene-specific primers with a fluorescence dye terminator in ABI PRISM 377 DNA Sequencer (Perkin-Elmer/ Applied Biosystem, Chiba, Japan). The nucleotide sequences were analyzed using Lasergene software (DNASTAR, Madison, WI, USA) and BLAST network service of NCBI (National Center for Biotechnology Information www.ncbi.nlm.nih.gov/). The sequences of three types of tilapia $17 \beta$-HSDs were deposited in GenBank under the accession numbers AY663853 (type 1), AY663855 (type 8) and AY663854 (putative type 12).
The sequences of all the primers used in this study are listed in Table 1.

\section{Phylogenetic analysis}

The multiple alignment software Clustal X (Thompson et al. 1997) was employed to analyze the homology and to calculate the phylogenetic trees by the neighborjoining (NJ) method using androgen-regulated shortchain dehydrogenase/reductase (ARSDR) as outgroup. Values on the tree represent bootstrap scores out of 1000 trials, indicating the credibility of each branch. The sequences of fugu $17 \beta$-HSDs used in the alignment were obtained from the fugu genome by the blast search with Japanese eel 17 $\beta$-HSD1, mouse $17 \beta$-HSD8 and human $17 \beta$-HSD12. The GenBank accession numbers of $17 \beta-$ HSD and ARSDR sequences used in this study are as follows: chicken-1 (BAA19567), human-1 (NP_000404), mouse-1 (NP_034605), rat-1 (NP_036983), fugu-1 (CAAB01001461·1), eel-1 (AAR88433), zebrafish-1 (AAP74564), tilapia-1 (AY663853), human-3 (NP_000188), rat-3 (NP_446459), mouse-3 (NP_032317), fugu-3 (CAAB01002155·1), zebrafish-3 (AAS58451), tetraodon-3 (CAF93282); human-8 (AAP36896), mouse-8 (P50171), pig-8 (AAD44802), medaka-8 (BAB83840), fugu-8 (CAAB01001220·1), zebrafish-8 (CAD54662), drosophila-8 (NP_570046), elegance-8 (NP_499346), tilapia-8 (AY663855); 
human-12 (AAP36605), mouse-12 (NP_062631), frog-12 (AAH41194), tilapia-12 (AY663854), fugu-12A (exon 1 (CAAB01002105·1), other exons (CAAB 01006992·1) (CAAB01006435·1)), fugu-12B (CAAB01002155·1), zebrafish-12A (AAH63943), zebrafish-12B (NP_955907), tetraodon-12A (CAG01042), tetraodon-12B (GAF99943), Yeast YBR159W (AAS58452); drosophila-ARSDR1 (NP_610310), human-ARSDR1 (AP_057110), mouseARSDR1 (AP_067532).

\section{Tissue distribution analysis of three types of $17 \beta-H S D s$ by RT-PCR}

Total RNA $(2 \cdot 0-5 \cdot 0 \mu \mathrm{g})$ was extracted from different tissues of adult fish. Reverse transcription was performed by using Super Script II (Gibco BRL, Gaithersburg, MD, USA) and Oligo-dT18 at $42{ }^{\circ} \mathrm{C}$ for $1 \mathrm{~h}$. DNase I (Invitrogen, Carlsbad, CA, USA) treatments were performed prior to reverse transcription to avoid contamination with genomic DNA. cDNA from various tissues was used as initial templates in RT-PCR for analysis of mRNA levels for different types of $17 \beta$-HSDs. For this purpose, we designed gene specific primers $\left(1-3 \mathrm{Fw}_{\mathrm{w}}, 1-4 \mathrm{Rv} ; 8-5 \mathrm{Fw}_{\mathrm{w}}, 8-6 \mathrm{Rv} ; 12-4 \mathrm{Fw}_{\mathrm{w}}\right.$, $12-8 \mathrm{Rv}$ ) from different exons of each type. The RT-PCR cycles were as follows: $94^{\circ} \mathrm{C}$ for $2 \mathrm{~min}$, followed by 30 to 36 cycles of $94{ }^{\circ} \mathrm{C}(30 \mathrm{~s}), 60{ }^{\circ} \mathrm{C}(30 \mathrm{~s})$, and $72{ }^{\circ} \mathrm{C}(1 \mathrm{~min})$, ending with $10 \mathrm{~min}$ of extension at $72{ }^{\circ} \mathrm{C}$. Positive and negative controls were set up with respective plasmid DNA and water as templates to validate the distribution patterns.

A 342 bp tilapia $\beta$-actin fragment was amplified (as internal control) to test the quality of the cDNA used in the PCR reactions (Wang et al. 2002). All the PCR products were electrophoresed using $1.5 \%$ agarose gels and the gels were stained with ethidium bromide to visualize bands.

\section{Northern blot analysis}

Northern blot was performed as per the method reported previously (Wang et al. 2002, Jiang et al. 2003). Briefly, total RNA was extracted from various tissues, such as gonad, liver, intestine and brain of both male and female fish using ISOGEN solution as per the manufacturer's protocol (Nippon Gene, Toyama, Japan). Poly $(\mathrm{A})^{+}$-RNAs were purified using Oligotex-dT30 (Takara, Otsu, Shiga, Japan). Then 5-8 $\mu \mathrm{g}$ mRNAs were applied to each well and were electrophoresed on a $1.5 \%(\mathrm{w} / \mathrm{v})$ formaldehyde denatured agarose gel, transferred onto Hybond-N+ nylon membrane (Amersham, Little Chalfont, Buckinghamshire, England) and baked at $80^{\circ} \mathrm{C}$ for $2 \mathrm{~h}$. The ORFs of three types of $17 \beta$-HSDs were labeled individually using Random Extension Plus kit (Dupont, Wilmington,
DE, USA). Hybridization was carried out at $60{ }^{\circ} \mathrm{C}$ in a hybridization solution containing $6 \times \mathrm{SSC}, 5 \times$ Denhardt's solution, $1 \%$ SDS and $200 \mu \mathrm{g} / \mathrm{ml}$ denatured herring sperm. The membranes were washed at $60{ }^{\circ} \mathrm{C}$ with a series SSC-SDS solution. The membranes were exposed to image plates and signals were analyzed using a BAS 2000 Bio-Imager analyzer. Subsequently, the blot was stripped and rehybridized with a ${ }^{32} \mathrm{P}$-labeled tilapia $\beta$-actin cDNA probe to serve as a positive control for loading variations.

\section{Production of recombinant proteins of tilapia $17 \beta-H S D s$}

Two gene specific primers $(1-5 \mathrm{Fw}, 1-6 \mathrm{Rv})$ were designed to introduce two restriction enzyme digestion sites at two ends of the 17 $\beta$-HSD1 ORF. Both purified PCR product and pETBlue2 vector (Novagen, Madison, WI, USA) were double digested to generate compatible overhangs for subsequent ligation. The recombinant plasmid was sequenced to confirm the correct insert and was subsequently transformed into E. coli. (DE3)pLacI strain for expression. The cells containing the recombinant construct were cultured at $37^{\circ} \mathrm{C}$ under Isopropyl- $\beta$-D-thiogalactopy anoside (IPTG) induction $(500 \mu \mathrm{M})$ for $6-10 \mathrm{~h}$ to obtain maximum production of the recombinant protein. The cells were then pelleted and lysed by sonication in the presence of lysozyme $(100 \mu \mathrm{g} / \mathrm{ml})$. After confirmation of the induction of recombinant protein by SDS-Polyacrylamide Gel Electrophoresis (SDS-PAGE), total proteins from the cell lysate were saved for the subsequent analysis of enzyme activity. Radioactive steroid substrates and mock (cells transformed with pETBlue-2 vector minus insert) were loaded as controls in these experiments.

Functional expression of $17 \beta$-HSD8 and putative $17 \beta$-HSD 12 was initially conducted using a bacterial expression system. However, we failed to get any enzymatic activity using the cell lysate. Assuming that some factors from the eukaryotic system are necessary for the normal function of these enzymes, we opted to use a mammalian expression system for the production of recombinant proteins of $17 \beta$-HSD types 8 and 12. The ORFs of $17 \beta-H S D 8$ (8-5Fw, $8-6 \mathrm{Rv}_{\mathrm{v}}$ ) and $17 \beta$-HSD12 $\left(12-9 \mathrm{~F}_{\mathrm{W}}, 12-10 \mathrm{Rv}\right)$ were amplified and cloned into TOPO pcDNA $3 \cdot 1$ (pcDNA3 $1 /$ /V5-His TOPO TA Expression Kit, Invitrogen, Carlsbad, CA, USA) to obtain respective recombinant constructs. After sequence confirmation, both constructs were transiently transfected into HEK 293 cells. Transient transfections were carried out using the Lipofectamine Reagent (Invitrogen, Carlsbad, CA, USA) according to the manufacturer's protocol. Briefly, $3 \times 10^{6}$ cells were seeded onto $10 \mathrm{~cm}$ tissue culture dishes before the day of transfection. For each culture dish, $24 \mu \mathrm{g}$ pcDNA $3 \cdot 1$ construct containing $17 \beta$-HSD8 or $17 \beta$-HSD12 was 


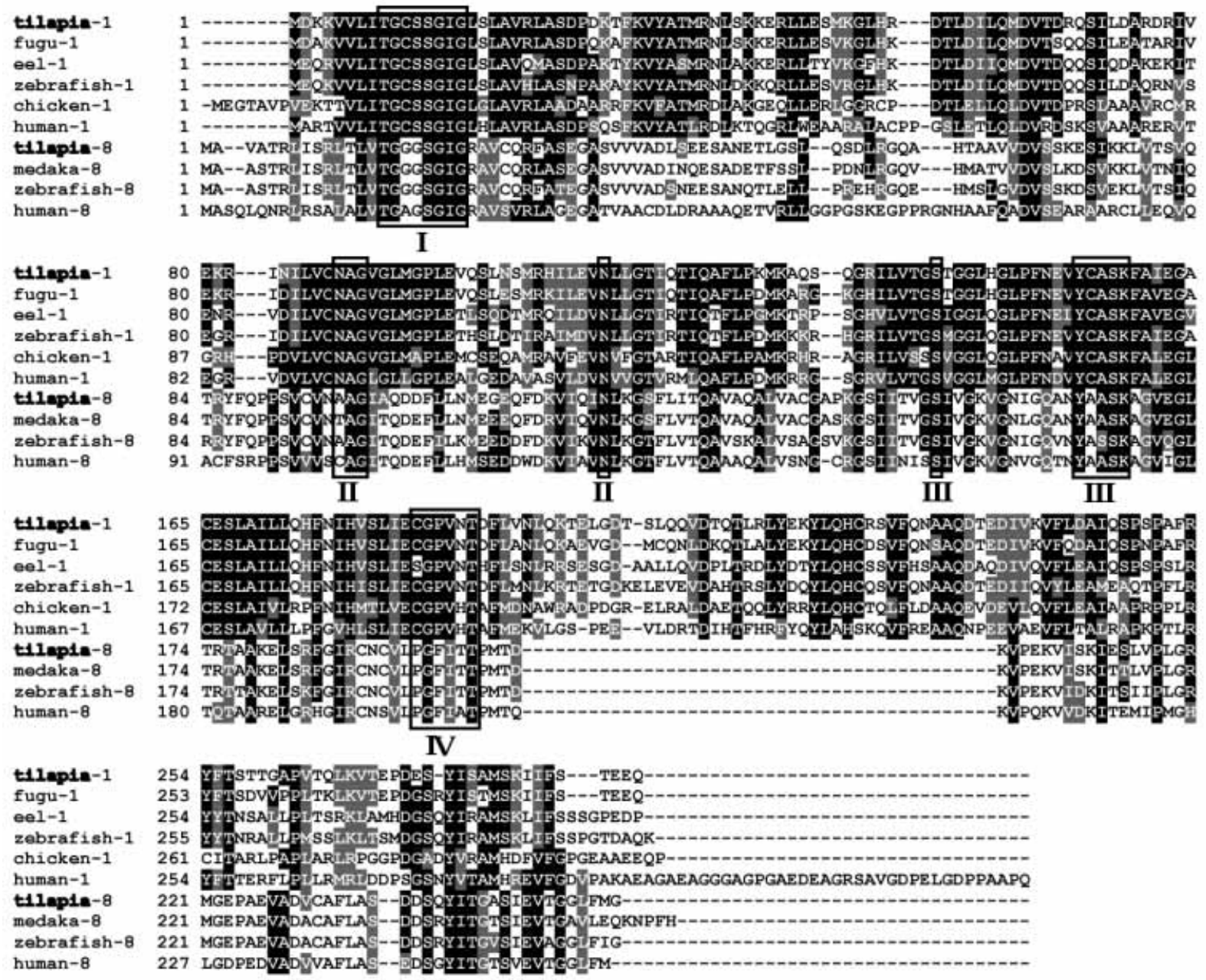

Figure 1 Alignment of $17 \beta$-HSD1 amino acid sequences of fish, chicken and human and 17 $\beta$-HSD8s of fish and human. BOXSHADE (http//www.ch.embnet.org/ software/BOX_form.html) was used to make this figure. Boxes I (coenzyme-binding motif), II (structurally conserved residues), III (catalytic center) and IV (motif for the determination of reaction direction) are the conserved motifs of the SDR superfamily. Refer to materials and methods for GenBank accession numbers.

transfected into the cells in $15 \mathrm{ml}$ Dulbecco's modified eagle's medium with $10 \%$ fetal bovine serum, and cultured at $37^{\circ} \mathrm{C}, 5.0 \% \mathrm{CO}_{2}$ for $24 \mathrm{~h}$. Vector pc DNA3 $1 /$ LacZ construct was used as a control for transfection efficiency. Cells were collected and cell lysates were saved for subsequent enzyme assay.

\section{Enzyme assay by thin layer chromatography (TLC)}

For each reaction, $10 \mu \mathrm{l}$ total cell lysate was diluted with $180 \mu \mathrm{l}$ buffer $\mathrm{A}((50 \mathrm{mM}$ potassium phosphate buffer $(\mathrm{pH}$ $7 \cdot 4)$ containing $1 \mathrm{mM}$ EDTA and $20 \%(\mathrm{~W} / \mathrm{V})$ glycerol $)$ and incubated with $3 \mu \mathrm{l}$ of ${ }^{14} \mathrm{C}$-labeled substrates ([4$\left.{ }^{14} \mathrm{C}\right]-\mathrm{T},\left[4-{ }^{14} \mathrm{C}\right]-\mathrm{A},\left[4-{ }^{14} \mathrm{C}\right]-\mathrm{E}_{1},\left[{ }^{4-}{ }^{14} \mathrm{C}\right]-\mathrm{E}_{2}$ in ethanol) $(0.02 \mathrm{mCi} / \mathrm{ml})$ (PerkinElmer, Boston, MA, USA) and $2 \mu \mathrm{l}$ coenzyme $(100 \mathrm{mM})(\mathrm{NAD}(\mathrm{P}) \mathrm{H}$ for reducing reaction and $\operatorname{NAD}(\mathrm{P})^{+}$for oxidizing reaction)). The reaction mixtures were incubated at $37^{\circ} \mathrm{C}$ for $4 \mathrm{~h}$, and the reactions were terminated by adding $200 \mu \mathrm{l}$ dichloromethane. The mixtures were shaken vigorously and centrifuged at 3000 r.p.m. for $10 \mathrm{~min}$. The lower organic layer was saved and the upper aqueous layer was re-extracted with $200 \mu \mathrm{l}$ dichloromethane. The combined organic layers were subjected to evaporation under nitrogen. The residual steroids were dissolved in $50 \mu \mathrm{l}$ ethanol and developed on silica gel TLG plate (5729, E. Merck, Darmstadt, Germany) by using dichloromethane/ethylacetate/ methanol (85:15:3 by volume) as the developing solvent system. The TLC plate was then air-dried and the radioactive spots were located by autoradiography, and 


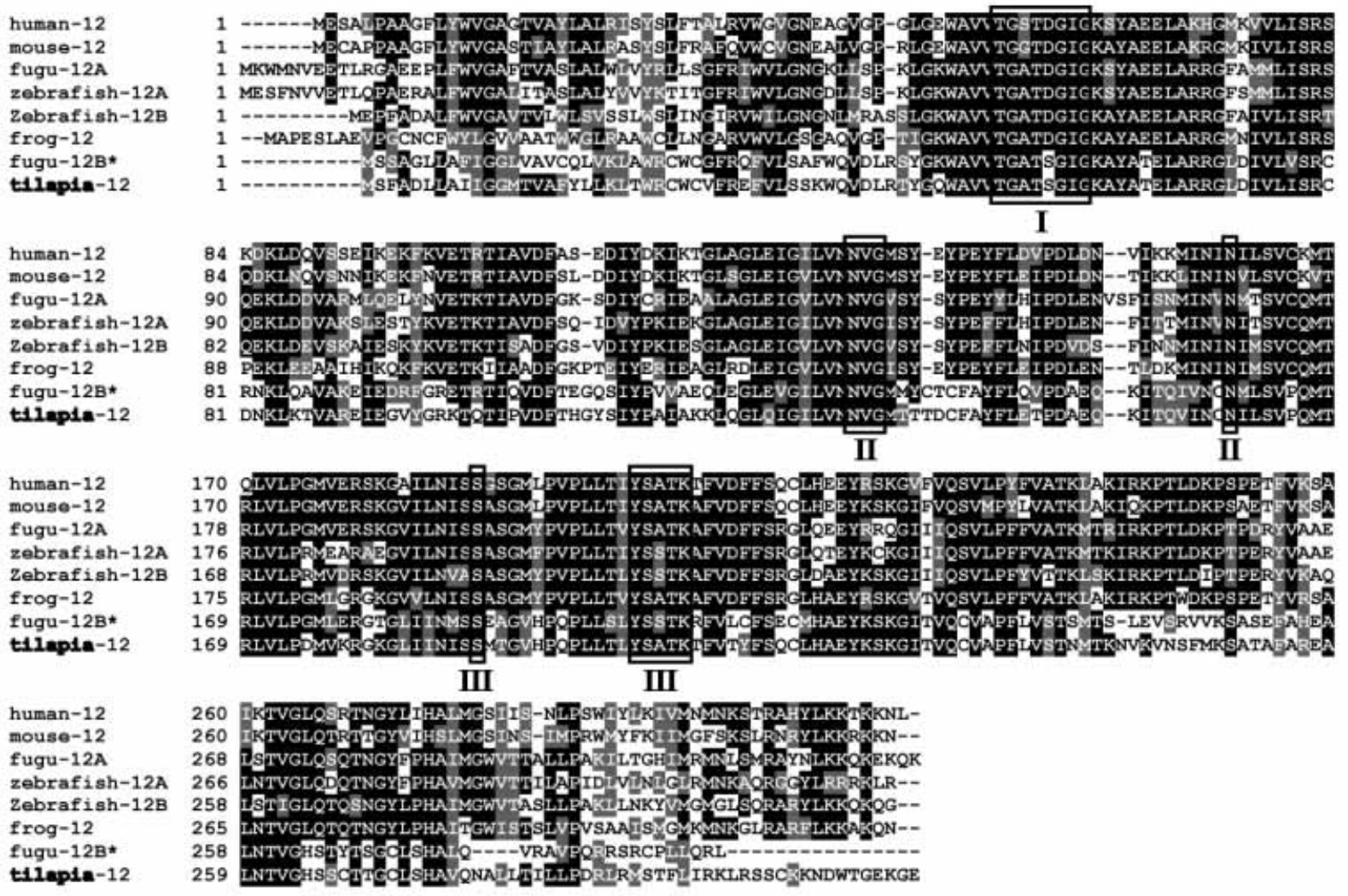

Figure 2 Alignment of the amino acid sequences of 17ß-HSD12s from mammals, frog and fish. Boxes I, II and III are the conserved motifs of the SDR superfamily as mentioned in Fig. 1. Refer to Materials and methods for GenBank accession numbers.

visualized by BAS 5000 bio-image analyzer (Fuji, Tokyo, Japan). The signal densities were quantified using Fuji-MacBAS software $(\mathrm{V} 1 \cdot 0)$.

The measurements with different substrates were done with the same lysate for the same enzyme in order to reduce the variation. For each substrate, the same amount of total radioactivity was added to each reaction tube. Conversion of $\mathrm{A}$ to $\mathrm{T}, \mathrm{T}$ to $\mathrm{A}, \mathrm{E}_{1}$ to $\mathrm{E}_{2}$ and $\mathrm{E}_{2}$ to $\mathrm{E}_{1}$ in the presence of $\mathrm{NAD}(\mathrm{H})$ or $\mathrm{NADP}(\mathrm{H})$ was calculated as a percentage of total radioactivity after extraction. Results are represented as means \pm S.E. of three independent measurements.

\section{Results}

\section{Molecular cloning of three type 17ß-HSDs}

After three rounds of library screening, nine positive clones of putative tilapia $17 \beta$-HSD1 were recovered. Subsequent sequence and blast analysis proved that they all encoded true tilapia 17 $\beta$-HSD1. It had high homology to $17 \beta$-HSD1 of human $(46 \cdot 6 \%)$, mouse $(46 \cdot 1 \%)$, chicken $(51 \cdot 4 \%)$, Japanese eel $(67 \cdot 6 \%)$ and fugu
$(83 \cdot 4 \%)$ at amino acid level. Based on the analysis of tilapia EST database (Wang, Ijiri and Nagahama unpublished data) and subsequent 5'-RACE, putative tilapia 17 $\beta$-HSD8 was obtained, and further analysis with blast revealed high similarity at amino acid level to its counterparts in human $(65.6 \%)$, mouse $(55.9 \%)$, zebrafish $(79 \cdot 3 \%)$ and fugu $(82 \cdot 1 \%)$. Tilapia putative $17 \beta$-HSD 12 cDNA was obtained by RT-PCR and RACE. Its deduced amino acid sequences showed high identity with $17 \beta$-HSD 12 of human $(40 \cdot 3 \%)$, mouse $(41 \cdot 7 \%$ ), zebrafish (about $41 \%$ to both type A and B), fugu $(39 \cdot 5 \%$ to type $\mathrm{A}, 60 \cdot 3 \%$ to type $\mathrm{B})$ and to $17 \beta$-HSD3 of human $(38.9 \%)$, mouse $(37 \cdot 4 \%)$ and zebrafish $(34 \cdot 5 \%)$.

The cloned cDNAs of tilapia 17ß-HSD type 1, 8 and 12 were 1504, 1006 and 1930 bp long, encoding proteins of 289, 256 and 314 aminoacids, respectively.

\section{Phylogenetic analysis}

$17 \beta-H S D s$ of the SDR family share several amino acid sequence motifs. These motifs include TGxxxGxG (a part of the Rossman fold for cofactor binding), NAG 


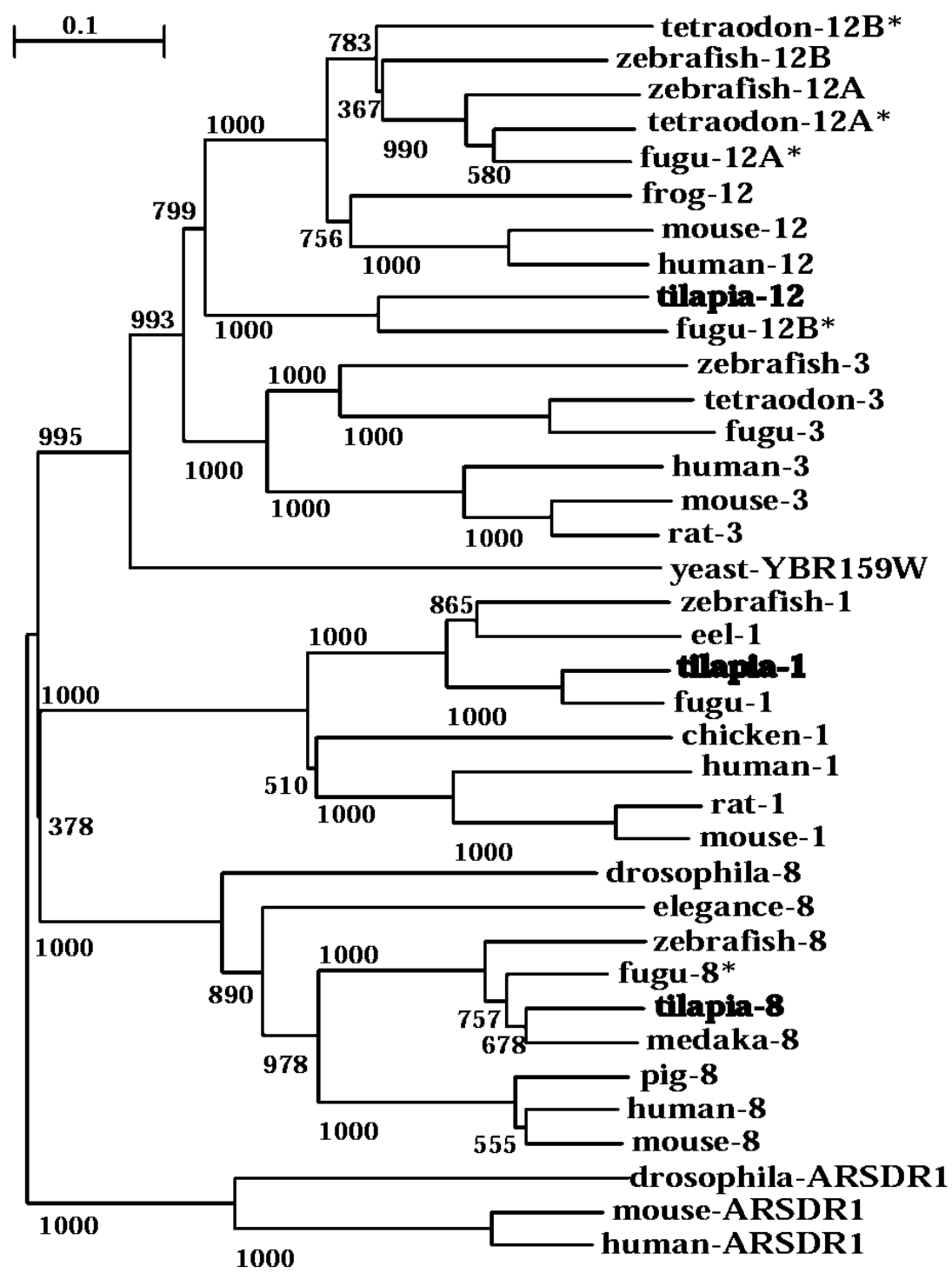

Figure 3 Phylogenetic analysis of three types of $17 \beta$-HSDs of vertebrates, insects and yeast using androgen-regulated short-chain dehydrogenase/reductase (ARSDR) as the outgroup. Numbers are the bootstrap values from 1000 replicates indicating credibility. Branch lengths are proportional to the number of amino acid changes on the branch. Partial sequences $\left({ }^{*}\right)$ may have artificially short branches. Close distance between tilapia and fugu 17 beta-HSD12s might be an artefact due to partial sequence known in fugu. Refer to Materials and methods for GenBank accession numbers.

(a region between cofactor binding and active sites for structural stabilization), YxxSK (active center) and PGxxxT (G-terminal to active site, determination of reaction direction). Outside these conserved regions sequence similarity might be as low as $20 \%$ (reviewed in Mindnich et al. 2004b).

Alignment of human, chicken and fish 17 $\beta$-HSD type 1 and 8 (Fig. 1), and human, frog and fish 17ß-HSD type 12 amino acid sequences (Fig. 2) revealed that the three types of tilapia $17 \beta$-HSDs possess the conserved motifs, such as TGxxxGIG (Box I), NAG (Box II) and YxxSK (Box III) of the SDR superfamily, except PGxxxT (Box IV). The latter is conserved only in types 1 and 8. Box I (TGCSSGIG) and Box III (YCASK) of tilapia $17 \beta$-HSD 1 are completely conserved as in all other vertebrates. This is also true for tilapia 17 $\beta$-HSD8 (Box I: TGGGSGIG, Box III: YAASK). However, the two boxes (Box I: TGATSGIG and Box III: 


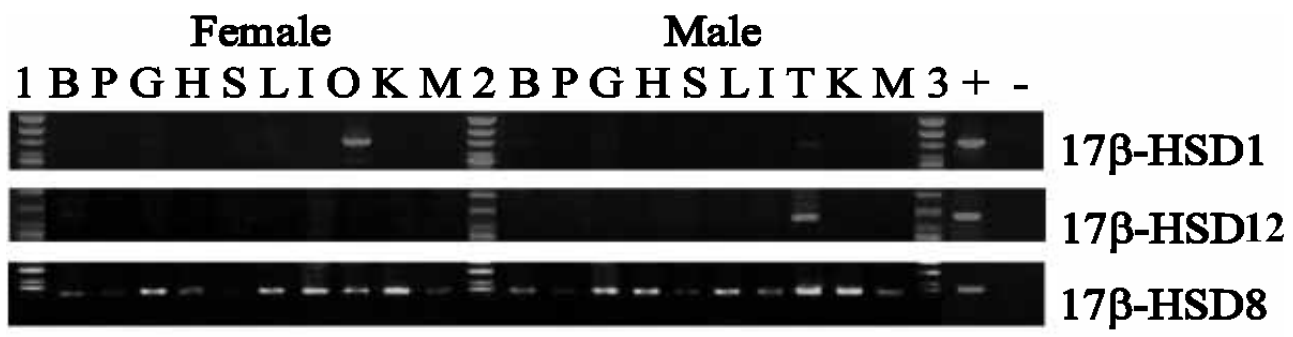

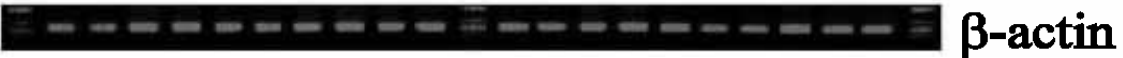

Figure 4 RT-PCR analysis of $17 \beta-H S D 1,17 \beta-H S D 8$ and $17 \beta-H S D 12$ from various tissues of adult tilapia. B, brain; P, pituitary; G, gill; H, heart; S, spleen; L, liver; I, intestine; O, ovary; K, kidney; M, muscle; T, testis; 1,2 , and 3 markers; +, positive control; -, negative control. Lower panel is for $\beta$-actin as internal control.

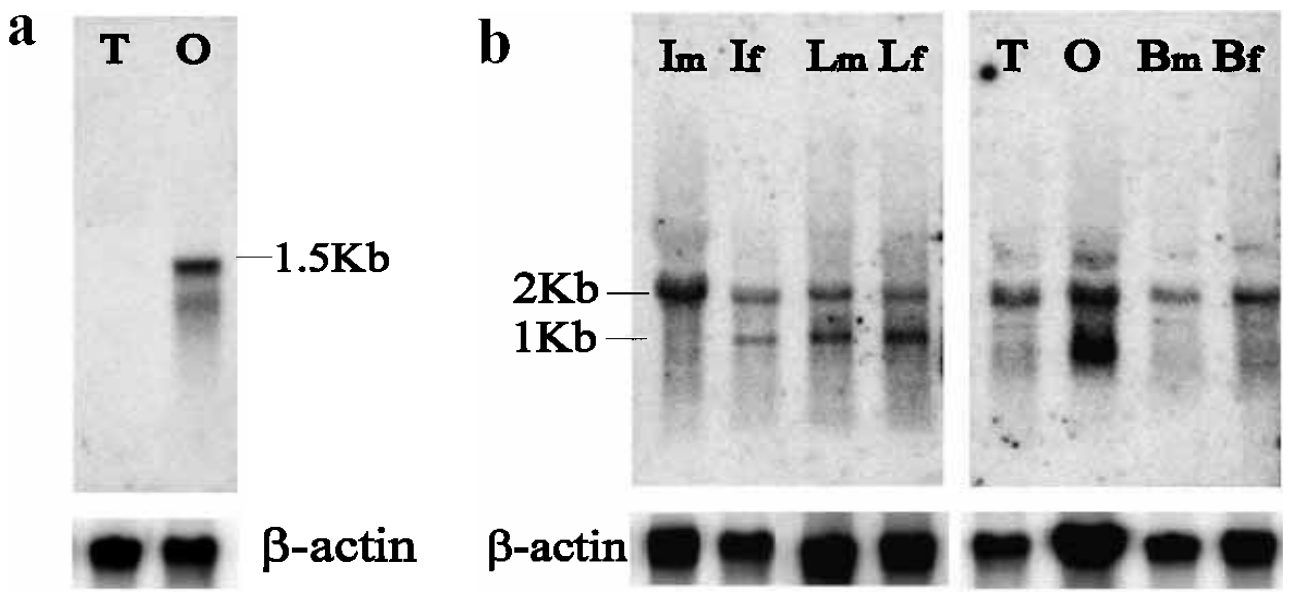

Figure 5 Northern blot analysis of poly $(A)^{+-R N A}(5-8 \mu \mathrm{g})$ from various tissues of tilapia by using 32P-17 $\beta$-HSD1 (a) and ${ }^{32} \mathrm{P}-17 \beta-\mathrm{HSD} 8$ (b) cDNA fragments. T, testis; O, ovary; Im, male intestine; If, female intestine; Lm, male liver; Lf, female liver; Bm, male brain; Bf, female brain. The lower panel shows the same membrane after stripping and hybridization with the tilapia ${ }^{32} \mathrm{P}-\beta$-actin probe.

YSATK) in putative tilapia $17 \beta-H S D 12$ are identical to those of fugu $12 \mathrm{~B}$ yet showed some sequence differences from conventional $17 \beta-H S D 12$ s cloned from tetrapod and other fish $12 \mathrm{As}$ and $12 \mathrm{Bs}$. The structurally conserved residues (Box II) showed some variation in three types of $17 \beta$-HSDs. These residues are NAG, xAG and NVG in type 1, type 8 and type 12 , respectively.

According to the alignment of the amino acid sequences of three types of $17 \beta$-HSDs cloned from vertebrates and insects, including sequences retrieved from the fugu genome, a phylogenetic tree was constructed (Fig. 3). Tilapia 17 $\beta$-HSD1 and 17 $\beta$-HSD8 were grouped into the corresponding phylogenetic clades as expected. Interestingly, two $17 \beta$-HSD 12 genes were found in fugu, tetraodon and zebrafish genomes. Phylogenetic analysis of putative tilapia $17 \beta$-HSD 12 with those in fugu, tetraodon and zebrafish indicated that these $17 \beta$-HSD 12s cluster into two distinct clades. The two $17 \beta$-HSD12s from tetraodon and zebrafish, as well as one of the two $17 \beta$-HSD12s identified from fugu genomes (we named it 12A) were grouped under one clade. This clade was also homologous to the $17 \beta$-HSD 12s found in other vertebrates including

Figure 6 (a) Enzyme assay of 17 $\beta$-HSD1 recombinant protein expressed in $E$. coli cells. Conversion of androstenedione (A) to testosterone $(T)$, T to $A$, estrone $\left(E_{1}\right)$ to estradiol $\left(E_{2}\right)$ and $E_{2}$ to $E_{1}$ in presence of $N A D(H)$ or $N A D P(H)$ was examined by thin layer chromatography (TLC) followed by autoradiography. As cell lysate instead of purified recombinant protein was used in the assay, the influence of native cofactors cannot be ruled out. Standard sample, radioisotope labeled standard substrates and mock, pETBlue 2 vector without insert. (b) Conversion calculated as a percentage of the total radioactivity after extraction. Results are represented as means \pm S.E. of three independent measurements. 
$\mathbf{a}$

14

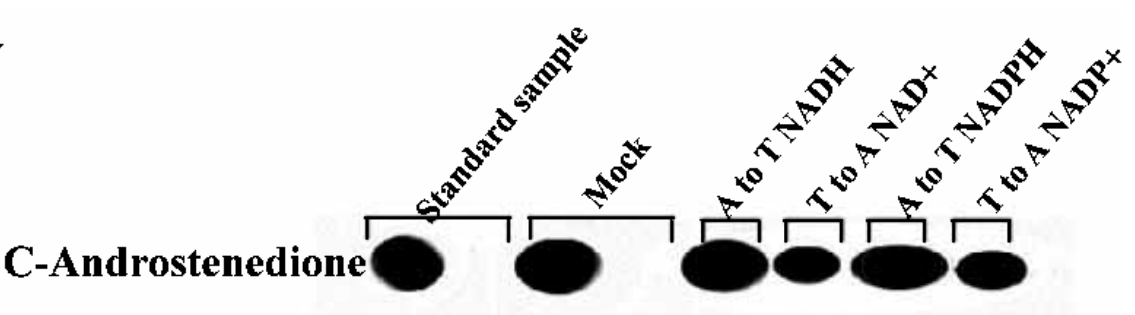

14

C-Testosterone
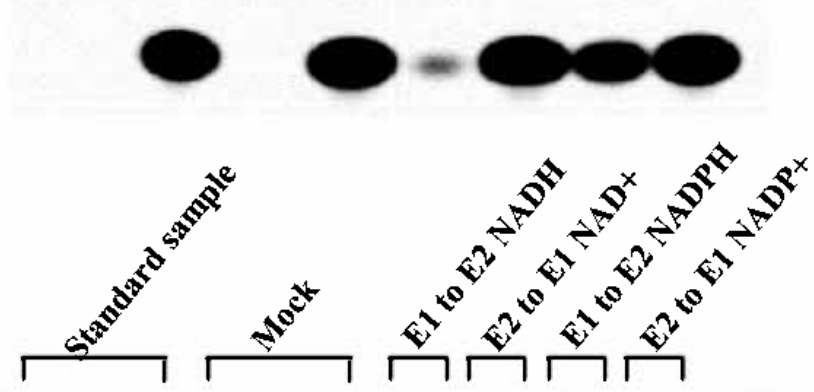

\section{4 \\ C-Estrone}

14 C-Estradiol

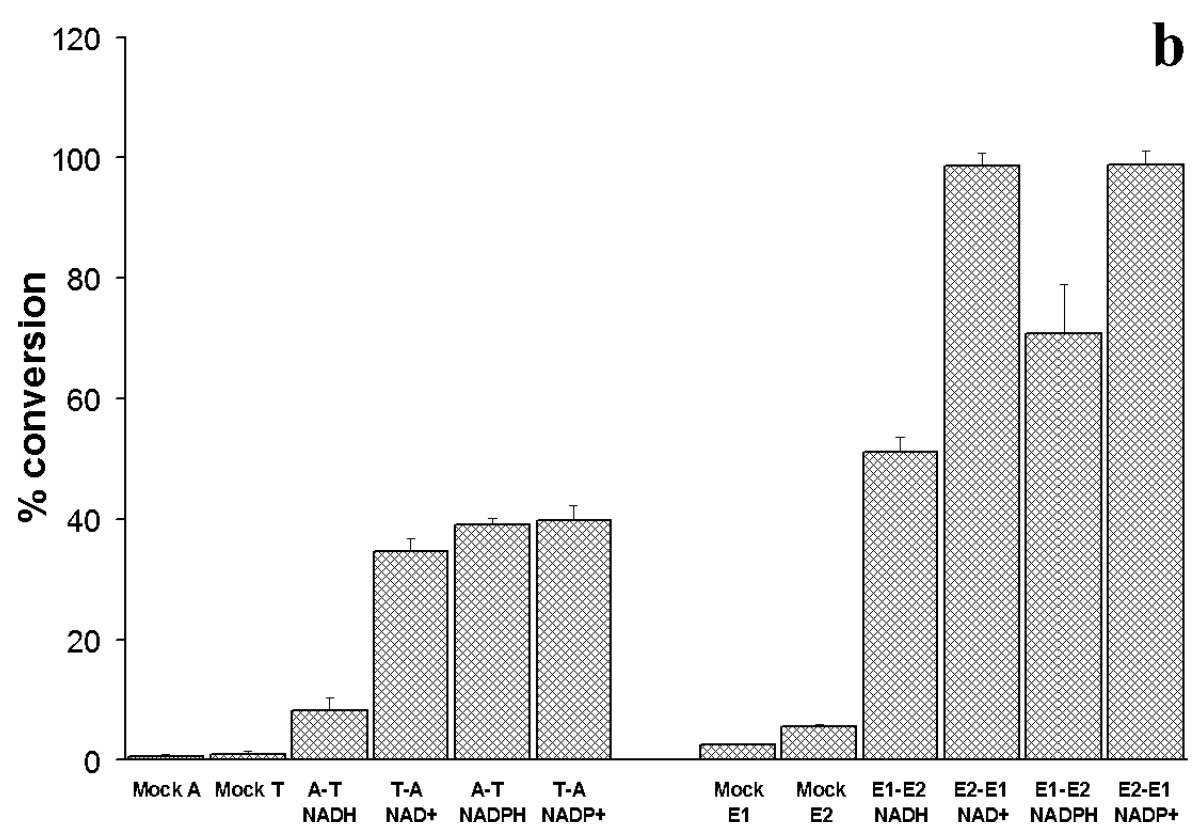


$\mathbf{a}$

14

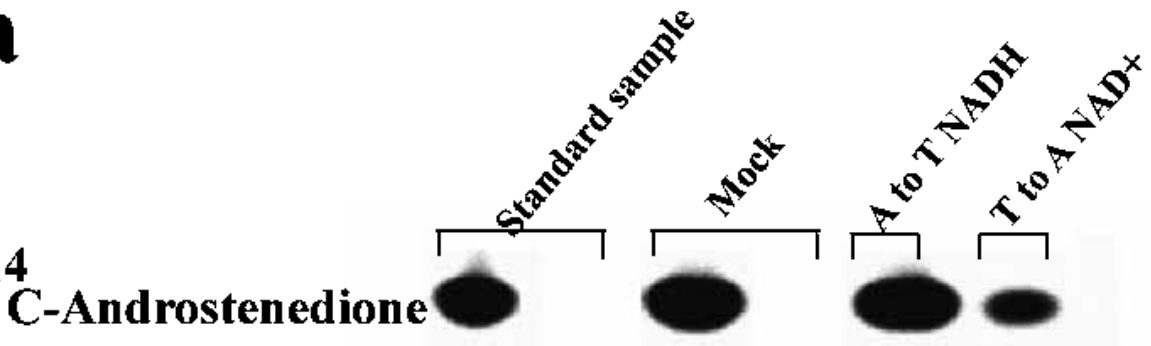

14

\section{C-Testosterone}

14

\section{C-Estrone}

\section{4 \\ C-Estradiol}
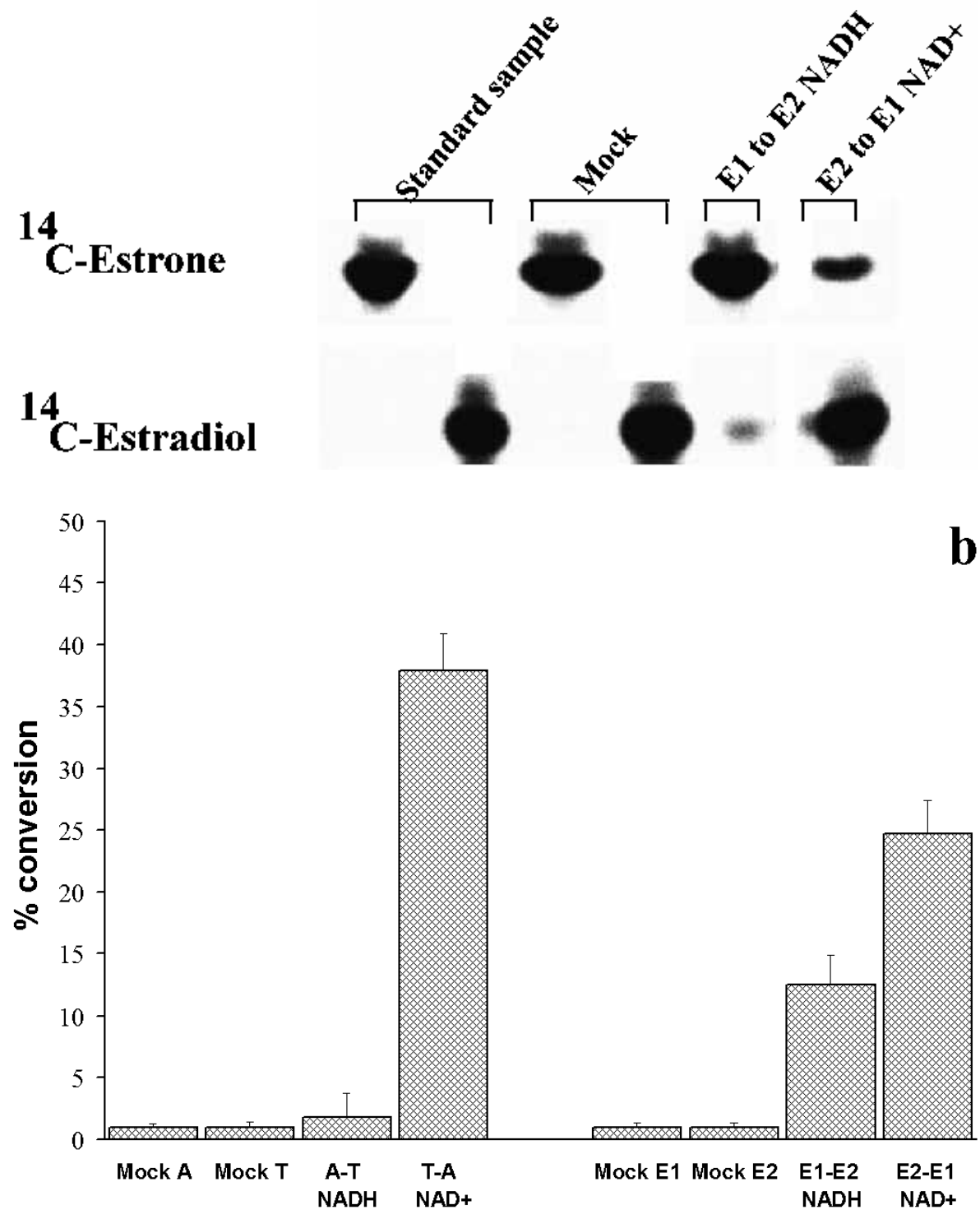
mammals. The other clade included the tilapia and fugu (we named it 12B) $17 \beta$-HSD12s.

\section{Tissue distribution analysis by RT-PCR}

Analysis of the tissue distribution pattern by RT-PCR revealed that tilapia $17 \beta$-HSD1 was expressed dominantly in the ovary while putative tilapia $17 \beta$-HSD 12 was expressed exclusively in the testis. A weak expression of $17 \beta$-HSD 1 was detected in the testis. On the other hand, tilapia $17 \beta-$ HSD8 was ubiquitously expressed in tissues such as brain, gill, heart, liver, intestine, gonad, kidney and muscle of both sexes (Fig. 4).

\section{Northern blot}

Results of Northern blot analysis of $17 \beta$-HSD1 and $17 \beta$-HSD8 were corroborative to those obtained by RT-PCR. A single band of $\sim 1.5 \mathrm{~kb} \quad 17 \beta$-HSD 1 transcript was detected in the ovary of tilapia, whereas no signal was found in testis (Fig. 5a). On the other hand, a $2 \cdot 0 \mathrm{~kb}$ transcript of $17 \beta-\mathrm{HSD} 8$ was observed in brain, liver, intestine and gonad of both sexes. Additionally, a transcript of $\sim 1 \cdot 0 \mathrm{~kb}$ was also detected in the ovary, intestine of female and liver of both sexes (Fig. 5b). However, no signal of putative $17 \beta$-HSD 12 was observed in this study when hybridized with mRNAs obtained from the gonads of both sexes, most probably due to the low sensitivity of Northern blot when compared with RT-PCR.

\section{Enzymatic assay by TLC}

Enzymatic assay of $17 \beta$-HSD1 was performed using the $17 \beta$-HSD1 recombinant protein expressed in E. coli. Tilapia $17 \beta-H S D 1$ showed preference for $\mathrm{NADP}(\mathrm{H})$ and it could inter-convert $\mathrm{E}_{1}$ and $\mathrm{E}_{2}$ efficiently, and also $\mathrm{A}$ and $\mathrm{T}$, though less efficiently (Fig. 6a). The percentages of conversion from $\mathrm{A}$ to $\mathrm{T}, \mathrm{T}$ to $\mathrm{A}, \mathrm{E}_{1}$ to $\mathrm{E}_{2}$ and $\mathrm{E}_{2}$ to $\mathrm{E}_{1}$, calculated as mean of triplicates, were $\sim 8 \cdot 25,34 \cdot 55$, 51.23 and $98.68 \%$, respectively in the presence of $\operatorname{NAD}(\mathrm{H})$. However, the corresponding conversion rates were higher in the presence of $\operatorname{NADP}(\mathrm{H}), \sim 39.06$, $39 \cdot 87,70 \cdot 82$ and $98 \cdot 85 \%$, respectively (Fig. 6b).

Enzymatic assays of $17 \beta-$ HSD8 and putative $17 \beta-$ HSD 12 were performed after expressing their recombinant proteins in HEK 293 cells. 17ß-HSD8 could catalyze the conversion from $\mathrm{T}$ to $\mathrm{A}$, as well as the inter-conversion between $\mathrm{E}_{1}$ and $\mathrm{E}_{2}$ in the presence of $\mathrm{NAD}(\mathrm{H})$ (Fig. 7a). The percentages of conversion from $\mathrm{T}$ to $\mathrm{A}, \mathrm{E}_{1}$ to $\mathrm{E}_{2}$ and $\mathrm{E}_{2}$ to $\mathrm{E}_{1}$, expressed as the means of three separate experiments, were $37.85,12.53$ and $24 \cdot 73 \%$ respectively (Fig. $7 \mathrm{~b}$ ).

However, the putative $17 \beta$-HSD 12 expressed in $E$. coli cells did not show any conversion to any of the substrates tested in this study. The results were unchanged even after using the HEK 293 cells expressing $17 \beta$-HSD12 recombinant protein.

\section{Discussion}

Previous reports showed that $17 \beta$-HSDls of human, mouse, rat, chicken, zebrafish and the Japanese eel were able to inter-convert $\mathrm{E}_{1}$ and $\mathrm{E}_{2}$ with preferential reduction of $\mathrm{E}_{1}$ than oxidation of $\mathrm{E}_{2}$ (Poutanen et al. 1993, Luu-The et al. 1995, Nokelainen et al. 1996, Akinola et al. 1996, Wajima et al.1999, Kazeto et al. 2000, Mindnich et al. 2004a). The amino acid residues Ser142, Tyr155, Lys159, His221 and Glu282, form part of the active center of $17 \beta-\mathrm{HSD} 1$ in humans and interact with the 3-OH of steroids' A-ring (Puranen et al. 1997, Huang et al. 2001). These residues are highly conserved in tilapia $17 \beta$-HSD 1 and therefore, it is reasonable to contemplate that tilapia $17 \beta$-HSD 1 catalyzes the conversion between $\mathrm{E}_{1}$ and $\mathrm{E}_{2}$. Our results clearly demonstrate the interconversion of $\mathrm{E}_{1}$ to $\mathrm{E}_{2}$. Moreover, tilapia $17 \beta$-HSD1 can also catalyze the conversion between $\mathrm{A}$ and $\mathrm{T}$ but less efficiently. Both rat and mouse $17 \beta$-HSD 1 could catalyze the conversion from $\mathrm{A}$ to $\mathrm{T}$ as efficiently as $\mathrm{E}_{1}$ to $\mathrm{E}_{2}$ (Akinola et al. 1996, Nokelainen et al. 1996). However, to our knowledge, our report is the first of its kind to demonstrate the catalytic activity of tilapia $17 \beta-$ HSD 1 to convert $\mathrm{T}$ to $\mathrm{A}$. Our data demonstrated that tilapia $17 \beta-H S D 1$ is indeed a multifunctional enzyme that might be involved in many different reactions in vivo in the steroidogenic pathway depending on its spatial and temporal expression pattern.

Our data also showed that tilapia 17ß-HSDl had preference to NADPH as cofactor and higher percentages of conversion were detected in reactions in the presence of $\mathrm{NADPH}\left(\mathrm{NADP}^{+}\right)$rather than of $\mathrm{NADH}$ $\left(\mathrm{NAD}^{+}\right)$. This is in accordance with the results obtained with human 17ß-HSD1 (Mazza et al. 1998, Lin et al. 2000). Residues that are critical for cofactor specificity in human 17 $\beta$-HSD1 (Leu36 and Ser12 l) are highly conserved in tilapia.

Figure 7 (a) Enzyme assay of 17 $\beta$-HSD8 recombinant protein expressed in HEK293 cells. Conversion of androstenedione (A) to testosterone $(T)$, T to $A$, estrone $\left(E_{1}\right)$ to estradiol $\left(E_{2}\right)$ and $E_{2}$ to $E_{1}$ in presence of $\operatorname{NAD}(H)$ was examined by thin layer chromatography (TLC) followed by autoradiography. As cell lysate instead of purified recombinant protein was used in the assay, the influence of native cofactors cannot be ruled out. Standard sample, radioisotope labeled standard substrates and mock, pcDNA3.1 vector without insert. (b) Conversion calculated as a percentage of the total radioactivity after extraction. Results are represented as means \pm S.E. of three independent measurements. 
Our former study showed that abundant expression of tilapia $17 \beta$-HSD1 was detected from day 0 to day 11 of the tilapia ovarian spawning cycle with the expression being sharply down regulated to undetectable levels at the day of spawning, day 14 (Zhou et al. 2003). The expression pattern of $17 \beta$-HSD1 indicates that this enzyme plays an essential role in the process of oocyte growth and vitellogenesis, which is consistent to the putative function attributed for cytochrome P450 aromatase (Yoshiura et al. 2003). In teleosts, the production of steroids in ovary follows the classical two cell type model system (Nagahama 2000). $\mathrm{E}_{2}$ and $17 \alpha$, $20 \beta$-dihydroxy-4-pregnen-3-one $\quad(17 \alpha, 20 \beta-\mathrm{DP})$ are known to be important for the oocyte growth and maturation, respectively (Nagahama 2000). A dramatic shift in the steroidogenic pathway from $\mathrm{E}_{2}$ to $17 \alpha$, $20 \beta$-DP production occurs just prior to the oocyte maturation. Consistently, the expression of two enzymes involved in the synthesis of $\mathrm{E}_{2}, 17 \beta$-HSD1 (Zhou et al. 2003) and cytochrome P450 aromatase (Yoshiura et al. 2003), were greatly decreased. On the other hand, the expression of $20 \beta-H S D$, the enzyme required for the production of $17 \alpha, 20 \beta$-DP was up regulated just before meiotic maturation (Senthilkumaran et al. 2002). These results together warrant the pivotal role played by $17 \beta$-HSD 1 synergistically with cytochrome P450 aromatase during vitellogenesis. Ontogeny of $17 \beta$-HSD1 revealed its initial expression around 35-50 days after hatching (dah) (data not shown), which is around the initiation of oogenesis, however, late in terms of sex differentiation. Therefore, this enzyme seems unlikely to be involved in the early estrogen or androgen biosynthesis during sex differentiation while its role in gametogenesis seems essential.

Previous reports showed that down regulation of the $\mathrm{Ke} 6$ gene is associated with three different recessive murine models of polycystic kidney disease, ovarian under-development and testicular abnormalities (reviewed in Fomitcheva et al. 1998). The enzymatic (17 $\beta$-HSD) property of Ke 6 to promote either estradiol synthesis (reduction) or inactivation (oxidation) of estradiol and testosterone could be important in the development of both the kidney and gonads as it may maintain optimal levels of sex steroids within these organs (Fomitcheva et al. 1998). In this study, enzyme assay by TLC showed that the recombinant protein of $17 \beta$-HSD8 could catalyze the conversion from $\mathrm{T}$ to $\mathrm{A}$, as well as the inter-conversion between $\mathrm{E}_{1}$ and $\mathrm{E}_{2}$ in tilapia. Additionally, the expression of $17 \beta$-HSD8 in gonads was found as early as 5 dah (data not shown), before the morphological sex differentiation, by EST sequencing and RT-PCR. Therefore, regulation of the intracellular levels of these steroids by Ke 6 and other $17 \beta$-HSDs might play an important role in the development of tilapia gonads. The ubiquitous expression pattern of $17 \beta$-HSD8, revealed by northern blot and RT-PCR might further indicate its role in the metabolism and regulation of peripheral steroids. Two transcripts were observed in our northern blot. As we performed northern blot in very high stringency conditions, we believe both of the two transcripts should be specific to the $17 \beta$-HSD8 ORF probe. The $3^{\prime}$-UTR of $17 \beta$-HSD8 was obtained by sequencing of the EST clones, which contained relatively short inserts. After 5 -RACE, the $17 \beta$-HSD8 cDNA we obtained is $1006 \mathrm{bp}$, which matches the $1 \mathrm{~kb}$ Northern blot band in size. The $2 \mathrm{~kb}$ band might be an alternatively spliced form of $17 \beta$-HSD8 with a relatively longer $3^{\prime}$-UTR. Ubiquitous distribution of the long form 17 $\beta$-HSD8 in the Northern blot is in accordance with the tissue distribution data obtained by RT-PCR. On the other hand, the expression of the short form is restricted to some tissues, such as ovary, female intestine and liver of both sexes, but not expressed in the brain of both sexes and male intestine. The functional significance of differential expression of these two differently spliced forms remains elusive.

Recently, two $17 \beta$-HSD12s were successfully cloned from zebrafish (Mindnich et al. 2004a). Through blast search we also retrieved two $17 \beta$-HSD12-like genes in both fugu and tetraodon genomes. The presence of two distinct types of $17 \beta$-HSD $12 \mathrm{~s}$ appears to be unique for fish and it might be due to gene duplication. However, phylogenetic analysis showed that the two $17 \beta-H S D 12 \mathrm{~s}$ of zebrafish and tetraodon, together with all $17 \beta$ HSD 12s from tetrapods were grouped in one clade whereas the putative tilapia $17 \beta-$ HSD 12 and fugu $17 \beta$-HSD12B were clustered into another clade. Therefore, our data cannot exclude the other possibility that putative tilapia $17 \beta$-HSD12 and fugu $17 \beta$-HSD12B in fact belong to an unidentified type of SDR, which shows high homology to both types 12 and 3 identified from tetraodon, zebrafish and some mammals. Tilapia $17 \beta$-HSD type 12 expressed exclusively in the testis of 50 day-old fish, which is in consistent with the results obtained from mammalian 173-HSD type 3 (Baker et al. 1997, Mustonen et al. 1997). On the contrary, all $17 \beta$-HSD type $12 \mathrm{~s}$, from zebrafish to human, were expressed ubiquitously in a wide variety of adult tissues such as brain, gonad, skin, liver and intestine in both sexes. Furthermore, both zebrafish $17 \beta$-HSD12 paralogs are expressed throughout embryogenesis. These data seem to suggest that putative tilapia $17 \beta$-HSD12 is similar to $17 \beta$-HSD3 but different from the conventional $17 \beta$-HSD 12 in gene expression pattern. However, unlike mammalian 17 $\beta$-HSD3, enzyme assays of the putative tilapia $17 \beta$-HSD 12 expressed in both HEK293 cells and $E$. coli cells did not show any conversion from A to $\mathrm{T}$ or vice versa in this study. As the expression of putative tilapia $17 \beta$-HSD12 recombinant protein was confirmed by SDS-PAGE and western blot (data not shown), the failure in enzyme assay can only be attributed to its unknown substrate specificity. Now that $17 \beta$-HSD 12 cloned from yeast to mammal exhibited a 
conserved function in the fatty acid metabolism (Beaudoin et al. 2002, Kuervers et al. 2003, Moon \& Horton 2003), further characterization of putative tilapia $17 \beta$-HSD 12 will be necessary to understand the molecular evolution and function of SDR family genes in fish.

In conclusion, three types of $17 \beta$-HSDs were cloned from the Nile tilapia in this study. Phylogenetic analysis, gene expression and enzyme characterization confirmed that the putative $17 \beta$-HSD type 1 and 8 cDNA encode genuine tilapia $17 \beta-H S D$ homologues. However, the putative $17 \beta$-HSD12 we cloned might be a paralog of the $17 \beta$-HSD12 duplicates found in fish or an unidentified SDR member in vertebrates. Further characterization of this clone will delineate the molecular evolution and function of $17 \beta-H S D s$ in vertebrates.

\section{Acknowledgement}

This work was supported in part by Grants-in-Aid for Research from CREST, JST (Japan Science Technology Corporation), and the Ministry of Education, Science, Culture and Sports, Japan. D S W, B S and C C S are grateful to Japan Society for Promotion of Science for Young Scientist fellowships. The authors declare that there is no conflict of interest that would prejudice the impartiality of this scientific work.

\section{References}

Akinola LA, Poutanen M \& Vihko R 1996 Cloning of rat 17 beta-hydroxysteroid dehydrogenase type 2 and characterization of tissue distribution and catalytic activity of rat type 1 and type 2 enzymes. Endocrinology 137 1572-1579.

Akinola LA, Poutanen M, Peltoketo H, Vihko R \& Vihko P 1998 Characterization of rat $17 \beta$-hydroxysteroid dehydrogenase type 1 gene and mRNA transcripts. Gene 208 229-238.

Baker PJ, Sha JH \& O'Shaughnessy PJ 1997 Localisation and regulation of 17 beta-hydroxysteroid dehydrogenase type 3 mRNA during development in the mouse testis. Molecular and Cellular Endocrinology 133 127-133.

Beaudoin F, Gable K, Sayanova O, Dunn T \& Napier JA 2002 A Saccharomyces cerevisiae gene required for heterologous fatty acid elongase activity encodes a microsomal beta-keto-reductase. Fournal of Biological Chemistry 277 11481-11488.

Bilbao JR, Loridan L, Audi L, Gonzalo E \& Castano LA 1998 Novel missense (R80W) mutation in 17-beta-hydroxysteroid dehydrogenase type 3 gene associated with male pseudohermaphroditism. European of Journal Endocrinology 139 330-333.

Fomitcheva J, Baker ME, Anderson E, Lee GY \& Aziz N 1998 Characterization of Ke 6, a new 17 beta-hydroxysteroid dehydrogenase, and its expression in gonadal tissues. Fournal of Biological Chemistry 273 22664-22671.

Guiguen Y 2000 Implication of steroids in fish gonadal sex differentiation and sex inversion. Current Topics in Steroid Research $\mathbf{3}$ 127-143.

Huang YW, Pineau I, Chang HJ, Azzi A, Bellemare V, Laberge S \& Lin SX 2001 Critical residues for the specificity of cofactors and substrates in human estrogenic $17 \beta$-hydroxysteroid dehydrogenase 1: variants designed from the three-dimensional structure of the enzyme. Molecular Endocrinology 15 2010-2020.

Jiang JQ, Wang DS, Senthilkumaran B, Kobayashi T, Kobayashi HK, Yamaguchi A, Ge W, Young G \& Nagahama Y 2003 Isolation, characterization and expression of 11 beta-hydroxysteroid dehydrogenase type 2 cDNAs from the testes of Japanese eel (Anguilla japonica) and Nile tilapia (Oreochromis niloticus). Fournal of Molecular Endocrinolology 31 305-315.

Kazeto Y, Ijiri S, Matsubara H, Adachi S \& Yamauchi K 2000 Cloning of 17 beta-hydroxysteroid dehydrogenase-I cDNAs from Japanese eel ovary. Biochemical and Biophysical Research Communications 279 451-456.

Kuervers LM, Jones CL, O’Neil NJ \& Baillie DL 2003 The sterol modifying enzyme LET-767 is essential for growth, reproduction and development in Caenorhabditis elegans. Molecular Genetics and Genomics 270 121-131.

Luu-The V, Zhang Y, Poirier D \& Labrie F 1995 Characteristics of human types 1, 2 and $317 \beta$-hydroxysteroid dehydrogenase activities: Oxidation/reduction and inhibition. The Fournal of Steroid Biochemistry and Molecular Biology 55 581-587.

Lin SX, Han Q Azzi A, Zhu D, Gangloff A \& Campbell RL 2000 $3 \mathrm{D}$-structure of human estrogenic 17 $\beta$-HSDl: binding with various steroids. The Foumal of Steroid Biochemistry and Molecular Biology 73183.

Matsuo MY, Asakawa S, Shimizu N, Kimura H \& Nonaka M 2002 Nucleotide sequence of the MHC class I genomic region of a teleost, the medaka (Oryzias latipes). Immunogenetics 53 930-940.

Moon YA \& Horton JD 2003 Identification of two mammalian reductases involved in the two-carbon fatty acyl elongation cascade. Fournal of Biological Chemistry 278 7335-7343.

Moghrabi N, Hughes IA, Dunaif A \& Andersson S 1998 Deleterious missense mutations and silent polymorphism in the human 17ß-hydroxysteroid dehydrogenase 3 gene (HSD17B3). Fournal of Clinical Endocrinology and Metabolism 83 2855-2860.

Mazza C, Breton R, Housset D \& Fontecilla-Camps JC 1998 Unusual charge stabilization of NADP+ in 17 $\beta$-hydroxysteroid dehydrogenase. Fournal of Biological Chemistry 273 8145-8152.

Mindnich R, Deluca D \& Adamski J 2004a Identification and characterization of $17 \beta$-hydroxysteroid dehydrogenases in the zebrafish, Danio rerio. Molecular and Cellular Endocrinology 215 19-30.

Mindnich R, Möller G \& Adamski J $2004 b$ The role of 17 beta-hydroxysteroid dehydrogenase. Molecular and Cellular Endocrinology 218 7-20.

Mustonen MV, Poutanen MH, Isomaa VV, Vihko PT \& Vihko RK 1997 Cloning of mouse 17 beta-hydroxysteroid dehydrogenase type 2, and analysing expression of the mRNAs for types 1, 2, 3, 4 and 5 in mouse embryos and adult tissues. Biochemical fournal $325 \quad 199-205$.

Nagahama Y 2000 Gonadal steroid hormones: major regulators of gonadal sex differentiation and gametogenesis in fish. In Proceedings of the $6^{\text {th }}$ International Symposium on Reproductive Physiology of fish, pp 211-222. Eds B Norberg, OS Kjesbu, GL Taranger, E Andersson \& SO Stefansson. Bergen, Norway.

Nokelainen P, Puranen T, Peltoketo H, Orava M, Vihko P \& Vihko R 1996 Molecular cloning of mouse $17 \beta$-hydroxysteroid dehydrogenase type 1 and characterization of enzyme activity. European Fournal of Endocrinology 236 428-490.

Oppermann UC, Salim S, Tjernberg LO, Terenius L \& Jornvall H 1999 Binding of amyloid beta-peptide to mitochondrial hydroxyacyl-CoA dehydrogenase (ERAB): regulation of an SDR enzyme activity with implications for apoptosis in Alzheimer's disease. Federation of European Biochemical Societies letters 451 238-242.

Penning TM 2003 Hydroxysteroid dehydrogenases and pre-receptor regulation of steroid. Human Reproduction Update 9 193-205.

Poirier D 2003 Inhibitors of $17 \beta$-hydroxysteroid dehydrogenases. Current Medical Chemistry $10453-477$. 
Poutanen M, Miettinen M \& Vihko R 1993 Differential estrogen substrate specificities for transiently expressed human placental $17 \beta$-hydroxysteroid dehydrogenase and an endogenous enzyme expressed in cultured COS-m6 cells. Endocrinology 133 2639-2644.

Poutanen M, Isomaa V, Peltoketo H \& Vihko R 1995 Role of 17 beta-hydroxysteroid dehydrogenase type 1 in endocrine and intracrine estradiol biosynthesis. Fournal of Steroid Biochemistry and Molecular Biology 55 525-532.

Puranen T, Poutanen M, Ghosh D, Vihko P \& Vihko R 1997 Characterization of structural and functional properties of human $17 \beta$-hydroxysteroid dehydrogenase type 1 using recombinant enzymes and Site-directed mutagenesis. Molecular Endocrinology 11 77-86.

Ramirez S, Fomitcheva I \& Aziz N 1998 Abnormal regulation of the Ke 6 gene, a new 17 beta-hydroxysteroid dehydrogenase in the cpk mouse kidney. Molecular and Cellular Endocrinology 143 9-22.

Senthilkumaran B, Sudhakumari CC, Chang XT, Kobayashi T, Oba Y, Guan G, Yoshiura Y, Yoshikuni M \& Nagahama Y 2002 Ovarian carbonyl reductase-like 20 $\beta$-hydroxysteroid dehydrogenase shows distinct surge in messenger RNA expression during natural and gonadotropin-induced meiotic maturation in Nile tilapia. Biology of Reproduction 67 1080-1086.

Sultmann H, Murray BW \& Klein J 2000 Identification of seven genes in the major histocompatibility complex class I region of the zebrafish. Scandinavian Fournal of Immunology 51 577-585.

Thompson JD, Gibson TJ, Plewniak F, Jeanmougin F \& Higgins DG 1997 The ClustalX windows interface: exible strategies for multiple sequence alignment aided by quality analysis tools. Nucleic Acids Research 24 4876-4882.

Wajima Y, Furusawa T, Kawauchi S, Wakabayashi N, Nakabayashi O, Nishimori K \& Mizuno S 1999 The cDNA cloning and transient expression of an ovary-specific 17 beta-hydroxysteroid dehydrogenase of chickens. Gene 233 75-82.

Wang DS, Kobayashi T, Senthilkumaran B, Sakai F, Sudhakumari CC, Suzuki T, Yoshikuni M, Matsuda M, Morohashi K \& Nagahama Y 2002 Molecular cloning of DAX1 and SHP cDNAs and their expression patterns in the Nile tilapia, Oreochromis niloticus. Biochemical and Biophysical Research Communications 297 632-640.

Yoshiura Y, Senthilkumaran B, Watanabe M, Oba Y, Kobayshi T \& Nagahama Y 2003 Synergistic expression of Ad4 BP/SF-1 and cytochrome P-450 aromatse (ovarian type) in the ovary of Nile tilapia, Oreochromis niloticus, during vitellogenesis suggests transcriptional interaction. Biology of Reproduction 68 1545-1553.

Zhou LY, Senthilkumaran B, Wang DS, Sudhakumari CC, Kobayashi T, Kajiura-Kobayashi H, Matsuda M, Yoshikuni M \& Nagahama Y 2003 Partial cloning of 17B-HSD1 from the Nile tilapia ovary and its expression pattern during spawning cycle. Fish Physiology and Biochemistry 28 381-382.

Received 29 March 2005

Accepted 25 April 2005

Made available online as an Accepted Preprint 12 May 2005 